\title{
Types of mixing and heterogeneities in siliciclastic-carbonate sediments
}

\author{
Domenico Chiarella ${ }^{1}$, Sergio G. LONGHitano ${ }^{2}$, MARCEllo Tropeano ${ }^{3}$ \\ ${ }^{1}$ Department of Earth Sciences, Royal Holloway University of London, Egham, Surrey TW20 0EX, UK \\ ${ }^{2}$ Department of Sciences, University of Basilicata, Italy \\ ${ }^{3}$ Dipartimento di Scienze della Terra e Geoambientali, Università degli Studi di Bari Aldo Moro, Italy
}

Keywords: mixed sediments; siliciclastic-carbonate; compositional mixing; strata mixing, heterogeneity, reservoir

\begin{abstract}
Mixed siliciclastic-carbonate deposits consist of a suite of different types of mixing between the two components, from bed (core-plug) to stratigraphic (seismic) scales, producing a high vertical and lateral lithological variability. Mixed deposits results from the interaction of siliciclastic input and coeval carbonate production controlled by temporal and/or spatial factors. Although mixed deposits are very diffuse in the geological record, studies about these deposits are scrappy and not well encoded. Accordingly, mixed deposits represent a labyrinth for researchers who want to investigate them for the first time.

In this paper, different types of mixing (compositional versus strata) controlled by different allocyclic (e.g. sea-level, climate) and/or autocyclic (e.g. depositional processes) factors that operate at different scale are documented. Mixing is recognized and described at three main scales of observation: bed/core-plug scale; lithofacies/well-log scale; and stratigraphic/seismic scale. (i) Compositional mixing reflects the contemporaneous accumulation of the two heterolithic fraction in space and time. This type of mixing is observable at lamina to bed scale, locally producing depositional structures diagnostic for particular depositional environments. (ii) Strata mixing results from the alternation of the two heterolithic fraction in time. This type of mixing is observable at lithofacies to stratigraphic scale and can be related to depositional processes, climatic variations and/or relative sea-level changes.
\end{abstract}

A correct identification of these different types of mixing and the scale of their occurrence is crucial in revealing (i) physical processes that control the sedimentation, (ii) environmental factors that influence the carbonate factory related to the siliciclastic dispersal mechanisms, and (iii) 
internal heterogeneity of the resulting sedimentary deposit. Furthermore, the petroleum industry is interested to unravel new insights about internal properties of mixed siliciclastic-carbonate systems (e.g., porosity, permeability) and to reconstruct predictive 3D models for the related reservoirs. The correct prediction of internal heterogeneity and the recognition of lateral and vertical compartmentalization have an important impact on hydrocarbon exploration and exploitation.

\section{Introduction}

Mixed or hybrid deposits are sediments consisting of both extrabasinal (e.g. epiclastic or terrigenous) and intrabasinal (autochthonous to parautochthonous) components (Zuffa, 1980; 1985). Since in the majority of cases the mixture comprises siliciclastic grains as extrabasinal fraction and carbonate grains (mainly bioclastic) as intrabasinal fraction, the most used definition for these hybrid materials is "mixed siliciclastic and carbonate sediments" (i.e. Mount, 1985). The mixing of these two components mostly derives from the interaction of different processes in the same basinal sector (e.g. river discharge in a shallow-marine area characterized by the presence of a carbonate factory), and consists in the mixture of siliciclastic and carbonate grains as well as the alternation of siliciclastic and carbonate laminas and lamina sets and/or strata and strata sets (e.g. Mount, 1984; Borer and Harris, 1991; Chiarella and Longhitano, 2012; Chiarella et al., 2012b; Longhitano et al., 2012). As a consequence, mixing between the two heterolithic components can occur with different proportion and scales according to different depositional processes, relative sea-level changes and/or climatic variations providing more sensitive records and complex sedimentation pattern than pure siliciclastic or carbonate systems.

The past two decades have witnessed a remarkable flourishing of research efforts devoted to the characterization of mixed sediments, and most recent studies on ancient and modern depositional environments indicate that mixed deposits are quite common and various (among others, Tirsgaard, 1996; Tropeano and Sabato, 2000; Anselmetti et al., 2004; Halfar et al., 2004; LaGesse and Read, 2006; Barnaby and Ward, 2007; Critelli et al., 2007; Messina et al., 2007; Hender and Dix, 2008; 
Amorosi e Zuffa, 2011; Betzler et al., 2011; Brandano et al., 2010; Tänavsuu-Milkeviciene et al., 2009; Longhitano et al., 2010; Zecchin and Caffau, 2011; Braga et al., 2012; Chiarella et al., 2012a; Gramigna et al., 2012; Longhitano et al., 2012; McNeill et al., 2012; Longhitano et al., 2014; Zeller et al., 2015; Chiarella et al., 2016; Moretti et al., 2016; Rossi et al., 2017; Van Loon et al, 2017). In particular, recent researches focused on: (i) the relationships between the two heterolithic fractions and the sedimentary processes (i.e. environmental conditions) that control mixed sedimentation, (ii) the environmental factors that influence the carbonate factory related to the siliciclastic dispersal mechanisms, and (iii) the mixed siliciclastic-carbonate distribution in space and time.

In addition, mixed deposits are valuable in the context of hydrocarbon exploration (McNeill et al., 2004) because carbonate and siliciclastic components play different roles in the different elements that characterize the petroleum system, as well as in oil migration, and reservoirs evolution. Consideration on how petrophysical properties of porosity and permeability vary throughout mixed deposits and identification of processes responsible for their creation and/or destruction are important for accurate reservoir modelling. Moreover, mixed deposits contain lateral and vertical heterogeneities (siliciclastic-carbonate layers) forming baffles and barriers that strongly influence flow behaviour.

In the present study, a classification of different types and scales of siliciclastic-carbonate mixing useful to characterize mixed reservoir formations is provided. Three different scales of mixing referable to two main types of mixing (compositional versus strata) are recognised.

\section{Components and classification of mixed siliciclastic-carbonate sediments: an historical}

\section{overview}

Only after a series of international meetings and many publications devoted to the occurrence of modern and ancient mixed systems, the study of mixed sediments received increased attention in the geologic literature (Zuffa, 1980; McIlreath and Ginsburg, 1982; Doyle and Roberts, 1988, Budd and Harris, 1990; Lomando and Harris, 1991). This was possibly due to the fact that mixed systems 
exhibit complex sedimentation patterns which depend on sedimentary processes active in terrigenous and/or carbonate systems interacting in the same sedimentary environments (Dolan, 1989). Consequently, the study of mixed systems usually requires a multidisciplinary approach, even if, until the 1980s, the attention of most sedimentologists was focused either on pure siliciclastic or on carbonate systems, with less attention paid to the spectrum of 'mixed' sediments that lies between the siliciclastic and carbonate end-members. Exemplary is the case of the Yates Formation (Guadalupe Mt, New Messico), which is an Upper Permian shelfal succession developed along the southwestern margin of the Delaware Basin (Borer and Harris, 1991a). Some publications described in detail its sedimentary features, focusing only on the carbonate facies, whereas others dealt only with the associated siliciclastic facies (Mear and Yarbrough, 1961; Zinz, 1971; Franco, 1973; Candelaria, 1982; Thorkelson, 1983). This approach was induced by a common misconception that a significant carbonate production cannot occur in areas of terrigenous input. Similarly, classification systems for clastic deposits are commonly presented according to the main lithological component (e.g. Dunham, 1962; Folk, 1980) although siliciclastic and carbonate sedimentation are part of a spatial and/or temporal continuum (Doyle and Roberts, 1988).

The most widely accepted and employed classification scheme for systematic description of sand-size sediments focused the attention on pure siliciclastic or carbonate sediments (e.g. Pettijohn, 1954; Folk, 1959; Dunham, 1962), although back in 1957 Pettijohn coined for the first time the term "calcarenaceous ortho-quartzite" for sandstone consisting of sub equal proportion of detrital carbonate and quartz. In the same year, Dumbar and Rodgers (1957) used "quartzose calcarenite" for intermediate varieties between sandstone where grains are dominantly of calcite (calcarenite), and sandstone where grains are dominantly of quartz (quartzose sandstone). Bramkamp and Powers (1958), in their classification of Arabian carbonate rocks, divided calcarenitic limestone into carbonate facies composed exclusively of carbonate grains, and sandy facies for detrital non-carbonate sand admixed with carbonate fragments. Successively, Pettijohn (1975) proposed the term "calcarenaceous sand" to define sandstone containing an appreciable 
amount of detrital carbonaceous particles. Mixed sediments can be referred to the "hybrid arenite" proposed by Zuffa (1980) and composed of an intrabasinal component typically represented by fragments of coeval carbonate skeletal organisms, and extrabasinal clastic fractions derived from river input or submarine erosion of previous substrate rocks. Mount (1984) proposed the terms "allochemic sandstone" with siliciclastic particles $>50 \%$, and "sandy allochem limestone" if allochems are dominant. Tucker (2003) re-adopted the term "calcarenaceous sandstones" previously proposed by Pettijhon (1975) for sediments that contain up to $50 \%$ of carbonate grains. Finally, Chiarella and Longhitano (2012), recently introduced the 'bioclastic/siliciclastic ratio', which allows assessing quantitatively the antithetic particle percentages appreciable in mixed unconsolidated or consolidated deposits, suggesting that sediments are considered mixed if they contain more than the $10 \%$ of their antithetic components.

\section{Different types and scales of mixing}

According to Budd and Harris (1990), mixed successions exhibit two different types of sedimentary mixing: (i) 'spatial variability', when siliciclastic and carbonate sediments lie adjacently, occupying laterally contemporaneous and contiguous environments (e.g. Dorsey and Kidwell, 1999; Coffey and Read, 2004; Nalin et al., 2010; Longhitano et al., 2010; Chiarella et al., 2012a, b; Longhitano et al., 2012), and (ii) 'temporal variability', when carbonate and siliciclastic sediments alternate through time along the same succession (e.g. Wilson, 1967; Gillespie and Nelson, 1997; McNeil et al., 2004; Moissette et al., 2010; Lee and Chough, 2011; Zecchin and Caffau, 2012). However, in some particular case, mixed successions can be characterized by a short-term spatial variability alternate to long-term temporal variability.

Unfortunately, these two types of mixing do not reflect the different scale of internal arrangement that can characterize mixed deposits. Based on the case studies reported in the present work, which are assumed to be fairly representative of a wide spectrum of mixing, a new characterization that takes into account also the different scales of internal organization is here 
proposed. In particular, based on their depositional arrangement mixed deposits can be classified as derived from a (i) compositional mixing or (ii) strata mixing (Fig. 1). The compositional mixing is referred to deposits in which the two heterolithic fractions accumulate contemporaneously in time and space resulting in millimetre- to meter-scale beds having a mixed siliciclastic-carbonate composition. The strata mixing is referred to deposits where the two heterolithic fractions are organized in meter- to decameter-scale interbedded siliciclastic and carbonate beds and/or bedsets. Compositional and strata mixing occur at three main scales of observation - bed (core-plug), lithofacies (core/well-log) and stratigraphic (seismic) scale - (Fig. 1). Recognition of the scale at which mixing occurs is important to better populated reservoir models with porosity and permeability properties for reservoir characterization.

\subsection{Compositional mixing}

Compositional-mixing occurs at the bed scale (core-plug scale) and it is generally related to depositional processes active during the sedimentation. Siliciclastic and carbonate particles are mixed during the sediment accumulation (Fig. 1A), because either they form the bulk of the transported sediment at time or the continuous feeding of terrigenous particles does not inhibit a significant in situ carbonate production (Chiarella et al., 2009; Chiarella, 2011; Longhitano et al., 2012; Chiarella, 2016; Chiarella et al., 2016). In the compositional mixing it is important to highlight that under the same hydrodynamic processes (e.g. waves, currents, tides) each heterolithic component may offer a different physical response. In fact, as the shear stress to the bottom or the velocity of a fluid flow cause grains motion, sedimentary particles respond depending on their specific density or morphometry (Mantz, 1977; Miller et al., 1977; Nelson, 1978; Allen, 1984; Clifton and Dingler, 1984; Komar and Clemens, 1986; Flemming, 2016). For instance, owing to their lower density and often platy or irregular shape, skeletal grains, even bigger than sand-size particles, require a lower shear stress to initiate transport if compared to siliciclastic grains (Maiklem, 1968; Braithwaite, 1973; Clifton and Dingler, 1984; Prager et al., 1996). For this reason, 
heterolithic sediments provide a different physical response if entrained by a fluid in motion (Collins and Rigler, 1982; Komar and Clemens, 1986), generating a specific internal organization of bioclastic and siliciclastic particles (Longhitano, 2011; Chiarella and Longhitano, 2012). This significant diversity may affect transport rates, causes differential sediment entrainment and lead to the formation of specific textural varieties in mixed deposits. As extensively documented in outcrop examples of southern Italy (see Figs. 4A-D), tidal currents and waves can organize mixed sediments in particular sedimentary structures indicative of specific waves- versus tide-influenced or dominated depositional environments (Chiarella, 2011; Chiarella et al., 2012; Longhitano et al., 2012; Chiarella and Longhitano, 2012). Thus, mixed sediments vary from unsegregated to variously segregated and can be organized into laminae or laminae-sets, depending on the in-situ production and hydrodynamics of the dominant process (Chiarella and Longhitano, 2012).

\subsection{Strata mixing}

Strata mixing can be related to either autocyclic or allocyclic factors. In this type of mixing, it is possible to recognize mixing that occurs from (a) lithofacies scale (core scale) to (b) stratigraphic scale (seismic scale) (Figs. 1B and 1C).

(a) Lithofacies scale mixing consists of interbedded siliciclastic and carbonate layers (Fig. 1B). As example, the Narva succession (Baltic Basin - Eastern Europe) shows a bed-scale (decimeter scale) alternation between siliciclastic and carbonate layers (Fig. 5A). This mixing can be interpreted as the result of: i) short-term sea-level changes, from highstand (carbonate layers) to lowstand (siliciclastic layers) (reciprocal sedimentation, in: Wilson, 1967); ii) short-term climate changes from arid (carbonate layers) to humid (siliciclastic layers) conditions or a tectonic control on the sediment supply from the continent (Tänavsuu-Milkeviciene et al., 2009); (iii) extreme weather conditions (e.g. storms) active during the sedimentation (Halfar et al., 2004); or (iv) heterolithic segregation related to gravity-driven depositional processes (Yose and Heller, 1989). 
(b) Stratigraphic scale mixing (Fig. 1C) can be related to the contemporaneous action of allocyclic and autocyclic factors. In the Parilla Formation (SE Spain), the stratigraphic scale mixing is interpreted to be related to the retrogradational (landward) shift of a carbonate marine environment above a siliciclastic alluvial-fan. In this Formation, mid-ramp deposits show 1 to 8 meters thick well-developed cycles of interbedded marine carbonates and marginal-marine to alluvial siliciclastics (Thrana and Talbot, 2006). A similar interfingered configuration between siliciclastic and carbonate units has been documented by Warzeski et al. (1996) and McNeill et al. (2004) in the Neogene of the South Florida (USA). In such shallow-marine deposits, according to McNeill et al. (2004), a combination of sea-level variations and current-velocity changes controlled the input of siliciclastic sediments into the mixing zone. In the Aínsa-Jaca Basin (Southern Pyrenees, Spain), Morsilli et al. (2012) describe the occurrence of carbonate buildups encased in siliciclastic prodelta deposits. To explain the contemporaneous existence of siliciclastic input and carbonate production, Sanders and Baron-Szabo (2005) and Morsilli et al. (2012) suggest that, below some threshold, distinctive taxa cope well with terrigenous turbidity acclimating by increased heterotrophy.

Furthermore, several authors (Martinius, 1995; Molenaar and Martinius, 1995; Monstad, 2000), refer to autocyclicity processes to interpret the formation of such alternating facies. Autocyclicity may develop as a consequence of the unforced internal dynamics of carbonate and siliciclastic sedimentation in association with subsidence (Thrana and Talbot, 2006). Tectonics movements can influence siliciclastic input through unroofing of the source area. Climate changes could influence siliciclastic sediment supply, carbonate productivity and sediment dispersal (Wilson, 1967; Capozzi and Picotti, 2003; Roveri and Taviani, 2003; García-García et al., 2009). Accordingly, carbonate intervals could correspond to episodic dry-cold climate conditions characterized by reduced siliciclastic supply. In contrast, siliciclastic intervals could correspond to temperate-wet climate stages characterized by high rate of siliciclastic supply produced by intense precipitation in the drainage areas. Finally, high-frequency sea-level changes can influence the relative importance of 
sediment supply versus carbonate production (Brachert et al., 2003; Chiarella and Longhitano, 2012).

\subsection{Coexistence of compositional and strata mixing}

In particular situations, compositional and strata mixing can occur in the same stratigraphic interval (Fig. 2).

Exemplary are the cases documented in the Catanzaro and the Enna-Caltanissetta basins (Southern Italy) and in the Guadix Basin (SE Spain) where a bed-scale compositional mixing is part of a stratigraphic-scale strata mixing. The basin-margin deposits of the Catanzaro Basin consist of a bed-scale compositional mixing closely alternating carbonate strata (Fig. 2A). These couples can be referred to gravity-driven depositional processes or short-term climatic changes (Chiarella et al., 2012a). The Capodarso Formation in the Enna-Caltanissetta Basin (Vitale, 1998; Colella and Vitale, 1998; Massari and Chiocci, 2006) consists of a stack of six mixed carbonate-siliciclastic wedge bodies ( 5 to $30 \mathrm{~m}$ thick) characterized by a bed-scale compositional mixing, alternating with siliciclastic mudstones (5 to $20 \mathrm{~m}$ thick) forming a stratigraphic-scale strata mixing (Fig. 2B). According to several authors (Lickorish and Butler, 1996; Vitale, 1998; Colella and Vitale, 1998; Roveri and Taviani, 2003; Massari and Chiocci, 2006 and Massari and D`Alessandro, 2010), the Capodarso stratigraphic architecture was controlled by high amplitude, orbitally-driven variations inducing glacio-eustatic and climatic changes.

The Guadix Basin succession (Fig. 2C) contains 30 sedimentary packages formed by mixed siliciclastic-carbonate sandstones (3-20 m thick) and homogeneous marls (2-17 m thick) (GarcíaGarcía et al., 2009 and Puga-Bernabéu et al., 2010). Likewise in the Capodarso Formation, a bedscale compositional mixing is part of a stratigraphic- (strata) mixing. The stratigraphic-scale alternation between mixed sandstones and marls has been interpreted as related to two different processes (García-García et al., 2009; Puga-Bernabéu et al., 2010). According to García-García et al. (2009), the repetition is related to alternating cool-wet and cold-dry climate episodes driven by 
precession orbital cycles with no substantial changes in the depositional depth. The siliciclasticcarbonate intervals, characterized by a compositional mixing (bed-scale), are interpreted to record wet temperate conditions, in contrast with the marl intervals attributed to cold-dry conditions. On the contrary, Puga-Bernabéu et al. (2010) interpret stratigraphic-scale mixing as controlled by relative sea-level changes.

An additional example showing contemporaneous compositional and strata mixing is the late Neogene shallow-marine Mao Formation (Cibao Basin - Dominican Republic). In this deposit McNeill et al. (2012) document the occurrence of 10 high-frequency cycles formed by siliciclastic layers interbedded with mixed carbonate-siliciclastic layers.

These examples confirm that pure siliciclastic and carbonate end-members do not pertain to two different realms but they are part of a continuum (sensu Doyle and Roberts, 1988). However, it is important to highlight that the occurrence of strata mixing requires a balance between terrigenous supply and carbonate production.

\section{Different mixing processes}

Based on modern and ancient examples, the compositional and strata mixing proposed in the present paper can be referred to three main mixing processes generating siliciclastic-carbonate mixtures (Fig. 3). (i) Punctuated mixing, which refers to isolated and occasional coexistences of carbonates with siliciclastics or vice versa (see also Mount, 1984), occurs because of catastrophic, high-intensity events, or is related to short-term climatic changes. Halfar et al. (2004) documents the occurrence of a punctuated mixing due to storm events in the present-day Gulf of California where siliciclastic sediments are eroded along the shorelines and redeposited onto carbonate sediments. This type of mixing process produces a lithofacies-scale mixing (strata mixing). (ii) Facies mixing represents mixing occurring along boundaries between contrasting, siliciclasticversus carbonate-dominated, environments. Possible examples are (a) flanks of carbonate shoal complexes that shelter siliciclastic lagoons, (b) siliciclastic tidal flats adjacent to sub-tidal 
carbonates; (c) coastal dunes and tidal flats receiving aeolian contributions of a different composition respect to the background sediments, (d) bioclastic beaches lying on the flanks of volcanic islands, which receive volcanoclastic sediments eroded from neighbouring areas; and (e) tidal straits, where siliciclastic dunes are often diffusely populated by living organisms with calcareous skeletal parts.. In the La Paz area (Gulf of California), facies mixing is documented adjacent to the shallow pocket bays and on mid-shelf environments where carbonate layers interfinger with siliciclastic ones (McNeill et al., 2012). This type of mixing can result both in a bed-scale mixing (compositional mixing) and/or a stratigraphic-scale mixing (strata mixing). (iii) In situ mixing refers to sediment mixtures related to contemporaneous availability in space and time of the two heterolithic siliciclastic and carbonate fractions. This type of mixing process results into a bed-scale mixing (compositional mixing). Here, siliciclastic sediments combine with carbonate material derived from autochthonous or parautochthonous faunal assemblages. In the Cibao Basin (Dominican Republic), the occurrence of carbonate deposits within a siliciclastic shelf result from an in situ mixing (McNeill et al., 2012), as well as documented in Quaternary deposits of southern Italy (Chiarella and Longhitano, 2012; Chiarella et al., 2012b; Longhitano et al., 2014; Chiarella, 2016; Chiarella et al., 2016).

\section{Reservoir considerations}

A variety of types and scales of heterogeneity is found in most reservoirs. Generally, the term heterogeneity is used to describe the geological complexity of a reservoir and the relationship of such complexity to the flow of fluids migrating through it (Slatt and Galloway, 1993). Porosity/permeability distribution due to lithologic and/or grain-size variation in the sedimentary deposits defines the reservoir heterogeneity (Bonnel and Hurich, 2008). The reservoir heterogeneity is further complicated by diagenesis and mechanical deformation of the rocks. Consequently, fluid flow in reservoirs is controlled by heterogeneity at different scales, from bed- (core-plug) up to stratigraphic- (seismic) scale. The two main rock properties that control reservoir performances are 
porosity and permeability, which are strictly dependent on texture and composition of the original sediment. In mixed deposits, the type and scale of mixing have a major impact on reservoir characterization. In particular, depositional processes control the primary sedimentary structures and the bed scale compositional mixing. Moreover, it is important to note that mixed sediments are subject to more rapid and extensive porosity loss owing to more compaction and cementation than in pure siliciclastic ones (Mansurbeg et al., 2009) although high porosity can be related to dissolution of carbonate grains in deeply buried mixed siliciclastic-carbonate strata (Feng et al., 2013). In the same way, understanding the processes that generate the strata mixing is important to elucidate the relationships between different mixed strata sets. This aspect needs is crucial when investigating lateral and vertical compartmentalization produced by the alternation of permeable (siliciclastic) and impermeable (carbonate) intervals (Zecchin and Caffau, 2012).

In the present paper, heterogeneities related to siliciclastic-carbonate mixing have been discriminated according to different scale of observations (Fig. 1). From smallest to largest scale, they are bed (core-plug) scale heterogeneities, related to compositional mixing, and lithofacies (core) scale and stratigraphic (seismic) scale heterogeneities, both related to strata mixing. In the literature, there are several examples of mixed siliciclastic-carbonate reservoirs related to compositional (e.g. well 6204/11-1, Shetland Group, offshore Norway) and strata (e.g. Asmari Reservoir, Marun oilfield, Iran; van Buchem et al., 2010; Gipsdalen Group, Barents Sea, Norway; Stemmerik et al., 1999) mixing, although they have not always been treated as mixed systems.

\subsection{Compositional mixing (Bed-/Core plug-scale)}

Bed (core-plug) scale mixing produce heterogeneities related to pores and textural arrangement of grains, including pore volume (porosity), pore sizes and shapes, grain-to-grain contacts that control permeability and grain types (siliciclastic versus carbonate). Consequently, heterogeneities at the bed (core-plug) scale affect directional flow of fluids, potential fluid-rock interactions, and formation damage. Reservoir properties of mixed siliciclastic-carbonate deposits characterized by a 
compositional mixing are strictly related to the twofold siliciclastic and carbonate grains composition. Because the capacity of mixed sediments to respond to the main hydrodynamic processes is strictly dependent upon their own physical features, the heterolithic composition controls the final internal texture of deposits (Chiarella and Longhitano, 2012). In addition, primary and secondary porosity can be controlled by the amount of carbonate grains mixed with the siliciclastic ones (Mansurbeg et al., 2009; Feng et al., 2013).

In many ancient examples of southern Italy, tidal processes segregate the predominantly coarse/light bioclastic and fine/heavy siliciclastic sediments forming typical siliciclastic-carbonate bundles in cross-stratified deposits (Chiarella, 2011; Longhitano, 2011; Chiarella and Longhitano, 2012; Chiarella et al., 2012; Longhitano et al., 2012; Longhitano et al., 2014 - Fig. 4A). This hydraulic partitioning provides distinct lateral changes in grain composition (siliciclastic versus carbonate) that could ultimately produce significant differences in reservoir potential. Consequently, hydraulic sorting results in a partitioning of reservoir facies forming siliciclastic- and bioclastic-rich foreset laminae with compartmentalized properties (Figs. 4A-D). Such variations in grain composition translate into differential diagenetic cementation within the laminae and, ultimately, to lamina-scale variations in permeability (Fig. 4C). Foresets act as minicompartments separated by high-angle angular unconformities, compositional and textural differences, and permeability baffles (Messina and Nemec, 2006; Messina et al., 2009; Longhitano, 2011). In particular, more cemented carbonate-rich laminae act as baffles to fluid flow. Cementation is enhanced by the presence of abundant carbonate grains, which can act as nuclei for precipitation and growth of carbonate cement (Mansurberg et al., 2009 and reference therein). Diagenetic evolution pathways are closely linked to the variation in sediments composition, particularly the proportions and types of siliciclastic and carbonate grains. For example, the diagenetic evolution and porosity reduction in mixed siliciclastic-carbonate turbiditic deposits of the Eocene Hecho Group show that mixed arenites undergo more rapid and extensive porosity loss owing to higher compaction and cementation than siliciclastic sandstones of the same succession (Mansurbeg et al., 
2009). Moreover, although reservoir performance generally decreases with depth, Feng et al. (2013) recognize in mixed deposits of the northwest Qaidam basin (China) two critical depths with higher porosity related to dissolution of carbonate grains.

Compartmentalization prediction is another crucial element to be evaluated in reservoir characterisation studies because permeability parallel to cross-strata is commonly up to four times greater than permeability normal to them, and anisotropy may have a strong effect on the flow of pore fluids, oil recovery and residual oil saturation (Kortekaas, 1985; Hartkamp-Bakker, 1991). In this case, fluid can migrate vertically only when faults or fractures create structural heterogeneities into the deposits.

Unfortunately, previous works focused mainly on flow behaviour in sandstone-mudstone systems (e.g. Dreyer, 1992; Ringrose et al., 2005 and reference therein) and no permeability data have been provided for mixed siliciclastic-carbonate deposits.

\subsection{Strata mixing}

Lithofacies (core) scale mixing may have an impact on the stratification styles and the nature of bedding contacts affecting fluid-flow patterns and drainage efficiency of reservoir (Slatt, 2006). The correct prediction of stratigraphic (seismic) scale mixing helps to estimate the in-place hydrocarbon volume, areal distribution, and trend of hydrocarbon production (Slatt and Galloway, 1993; Slatt, 2006).

The vertical and lateral lithological facies changes between carbonate and siliciclastic strata (Figs. 2, and 5A) can form stratigraphic traps based on lithologic differences and differential diagenesis resulting in alternating permeable (reservoir) and cemented (non-reservoir - barrier) meter-scale intervals, with erratic lateral and vertical distribution of pressures and fluids. In particular, if one of the interbedded lithofacies has high porosity and permeability values and the other is relatively tight, these reservoir prone beds could produce subsurface reservoir zones and subtle stratigraphic traps (McNeill et al., 2004). Accordingly, in well core the reservoir units would 
appear to be vertically stacked, separated by the non-reservoir lithologies. Therefore, the recognition of the lithofacies mixing is important because one of the heterolithic lithofacies may form impermeable layers (compartmentalized reservoir) acting as barriers to fluid flow, as well as potential source rocks (Emery and Myers, 1996). Finally, at the stratigraphic scale (Figs. 5B and 5C), the occurrence of alternating siliciclastic and carbonate units could correspond to different reservoir and non-reservoir zones. The proposed example of the Aínsa-Jaca Basin of southern Pyrenees (Spain) may reproduce this situation having carbonate units embedded within siliciclastic ones (Fig. 5C). In the same way, the stacking pattern of siliciclastic-carbonate cycles (stratigraphic scale mixing) recognized in the Yates Formation in the Guadalupe Mt (New Mexico) (Borer and Harris, 1991a; 1991b; Mutti and Simo, 1993) produces stacked reservoir (siliciclastic unit) and nonreservoir (carbonate unit) intervals. The positioning of vertical and lateral facies shifts depends on the understanding of the stratigraphic architecture of the mixed system, which is related to the same factors controlling the strata mixing.

In similar compartmentalized subsurface siliciclastic reservoir intervals, fluid migration pathways are parallel to the stratification, and fluids may migrate vertically only if and where vertical discontinuities (e.g. faults or fractures) penetrate the cemented carbonate layers (Zecchin and Caffau, 2012).

Understanding vertical and lateral changes in composition, and reservoir properties at the bed and regional scale is fundamental to predict the occurrence of potential reservoir and non-reservoir intervals. Therefore, integration between outcrop-scale (field and digital) studies and subsurface data (core and seismic) is useful to reconstruct a sedimentological and stratigraphic framework, and is essential for the elaboration of $3 \mathrm{D}$ reservoir models.

\section{Conclusions}

Although in the last years an increasing number of researchers pointed their attention on mixed deposits, uncertainties do still exist about reservoir properties, internal organization, heterogeneities, 
and environmental conditions that characterize this particular kind of deposits that lie between the siliciclastic and carbonate realms. The main uncertainty growth up because the study of mixed deposits must be different if compared with the analytical approaches usually performed on pure siliciclastic or carbonate sediments or sedimentary rocks, and a mixture of experiences and methodologies coming from both siliciclastic and carbonate worlds is needed. For example, for the study of the bed-scale mixing it is important to investigate and understand the hydrodynamic processes that control the distribution and organization of sediments, because the hydraulic regime (e.g. high-/low-energy currents or waves) can potentially affect the distribution of the carbonate factory within the depositional system.

This paper illustrates that proper characterization of the spatial and temporal organization of the two heterolithic siliciclastic and carbonate fractions in mixed deposits can be a useful tool for reservoir quality characterization of mixed siliciclastic-carbonate systems. Mixed systems comprise a class of very different sizes of mixing from bed- to stratigraphic-scale, in which estimation of reservoir properties is challenging. Therefore, the study of mixed deposits can be important to detect the physical factors that influence the spatial distribution of mixed siliciclastic-carbonate sediments and thus identify characteristics of potential reservoir facies. In particular, recognition of temporal and spatial relationships between siliciclastic and carbonate sediments is important in that the original textural lithofacies control the porosity and permeability development in ancient rocks.

Accordingly, we propose two main types of mixing:

- compositional mixing occurring at the bed (core-plug) scale;

- strata mixing occurring at the lithofacies- (core) and stratigraphic- (seismic) scale.

The lateral and vertical alternation (compartmentalization), at different scales of observations, between cemented and more porous intervals leads to a heterogeneity of the potential reservoir. This aspect is most important and needs to be taken into account for a profitable hydrocarbon exploration and production, because lateral and vertical compartmentalization may influence the fluid migration pattern and the effective volume of the reservoir. 


\section{AKNOLEDGEMENTS}

Domenico Chiarella would like to acknowledge Camilla Thrana, Fernando García and Ángel Puga-Bernabéu for providing photos of Spanish examples, and Mauro Aldinucci, Wojtek Nemec and former colleagues in Point Resources (Norway) for stimulating discussion about mixed deposits. Constructive reviews by Claudio Di Celma, Massimo Zecchin and an anonymous reviewer are gratefully acknowledged.

\section{REFERENCES}

Allen J.R.L., 1984. Sedimentary structures: their character and physical basis. Development in Sedimentology 30, Unabridged One-Volume, Elsevier, 1256 p.

Amorosi A., Zuffa G.G., 2011. Sand composition changes across key boundaries of siliciclastic and hybrid depositional sequences. Sedim. Geol. 236, 153-163.

Anselmetti F.S., Isern A.R., Blum P., Betzler C., 2004. Proceeding of the ocean drilling program. Sci. Results, 194.

Barnaby R.J., Ward W.B., 2007. Outcrop analog for mixed siliciclastic-carbonate ramp reservoirs-stratigraphic hierarchy, facies architecture, and geologic heterogeneity: Grayburg Formation, Permian basin, U.S.A. J. Sediment. Res., 77, 34-58.

Betzler C., Braga J.C., Jaramillo-Vogel D., Römer M., Hubscher C., Schmiedl G., Lindhorst S., 2011. Late Pleistocene and Holocene cool-water carbonates of the Western Mediterranean Sea. Sedimentology, 58, 643-669.

Bonnel B. and Hurich C., 2008. Characterization of reservoir heterogeneity: an introduction of the role of cross-well reflection data. CSEG Recorder

Borer J.M., Harris P.M., 1991a. Depositional facies and model for mixed siliciclastics and carbonates of the Yates Formation, Permian Basin. In: Lomando AJ, Harris PM (Eds) Mixed Carbonate - Siliciclastic sequences, Core Workshop, 15, SEPM, Dallas, pp. 1-134.

Borer J.M., Harris P.M., 1991b. Lithofacies and cyclicity of the Yates Formation, Permian Basin: Implications for reservoir heterogeneity: Am. Ass. Petr. Geol. Bull., 75, 726-779.

Brachert T.C., Forst M.H., Pais J.J., Legoinha P., Reijmer J.J.G., 2003. Lowstand carbonates, highstand sandstones? Sediment. Geol. 155:1-12.

Braithwaite C.J.R., 1973. Settling behaviour related to sieve analysis of skeletal sands. Sedimentology, 20, 251-262.

Bramkamp R.A., Powers R.W., 1958. Classification of Arabian carbonate rocks. Geol. Soc. Am. Bull., 69, 1305-1318.

Braga J.C., de Neira A.D., Lasseur E., Mediato J., Aguirre J., Abad M., Hernaiz-Huerta P.P., Monthel J., Pérez-Valera F., Lopera E., 2012 Pliocene-Lower Pleistocene shallow-water mixed siliciclastics and carbonates (Yanigua and Los Haitises formations) in eastern Hispaniola (Dominican Republic). Sediment. Geol., 265-266, 182-194. 
Brandano M., Tomassetti L., Bosellini F., Mazzucchi A., 2010. Depositional model and paleodepth reconstruction of a coral-rich, mixed siliciclastic-carbonate system: the Burdigalian of Capo Testa (northern Sardinia, Italy). Facies, $56,433-444$.

Budd D.A., Harris P.M., 1990. Carbonate-Siliciclastic Mixtures, SEPM Reprint Series.

Candelaria M.P., 1982. Sedimentology and depositional environment of upper Yates Formation siliciclastic (Permian, Guadalupe), Guadalupe Mountains, southeast New Messico. Master Thesis, University of Wisconsin, Madison.

Capozzi R., Picotti V., 2003. Pliocene sequence stratigraphy, climatic trends and sapropel formation in the Northern Apennines (Italy). Palaeogeogr. Palaeoclimatol. Palaeoecol., 190, 349-371.

Chiarella D., 2011. Sedimentology of Pliocene-Pleistocene mixed (lithoclastic-bioclastic) deposits in southern Italy (Lucanian Apennine and Calabrian Arc): depositional processes and palaeogeographic frameworks. PhD Thesis, University of Basilicata.

Chiarella D., 2016. Angular and tangential toeset geometry in tidal cross $\square$ strata: An additional feature of current $\square$ modulated deposits. In: Tessier, B., Reynaud, J.-Y. (Eds.), Contributions to Modern and Ancient Tidal Sedimentology: Proceedings of the Tidalites 2012 Conference. IAS Spec. Publ., 185-195

Chiarella D., Longhitano S.G., 2012. Distinguishing depositional environments in shallow-water mixed bio-siliciclastic deposits on the base of the degree of heterolithic segregation (Gelasian, Southern Italy). J. Sediment. Res., 82, 962990

Chiarella D., Longhitano S.G., Muto F., 2009. Sedimentary features of Lower Pleistocene mixed Lithoclastic-Bioclastic deposits in a fault-bounded basin, Catanzaro Basin, (Southern Italy). Fist Geoitalia 2009 p. 399.

Chiarella D., Longhitano S.G., Muto F., 2012a. Sedimentary features of the Lower Pleistocene mixed siliciclasticbioclastic tidal deposits of the Catanzaro Strait (Calabrian Arc, south Italy). Rend. Soc. Geol. Ital., 21, 919-920.

Chiarella D., Longhitano S.G., Sabato L., Tropeano M., 2012b. Sedimentology and hydrodinamics of mixed (siliciclastic-bioclastic) shallow-marine deposits of Acerenza (Pliocene, Southern Apennines, Italy). Ital. J. Geosci. 131:136-151

Chiarella, D., Moretti, M., Longhitano, S.G., Muto, F., 2016. Deformed cross-stratified deposits in the Early Pleistocene tidally-dominated Catanzaro strait-fill succession, Calabrian Arc (Southern Italy): triggering mechanisms and environmental significance. Sediment. Geol. 344, 277-289.

Clifton H.E., Dingler J.R., 1984. Wave-formed structures and paleoenvironmental reconstruction. Marine Geology 60, 165-198.

Coffey B.P., Read J.F., 2004. Mixed carbonate-siliciclastic sequence stratigraphy of a Paleogene transition zone continental shelf, southeastern USA. Sediment. Geol. 166, 21-57.

Colella A., Vitale F.P., 1998. Eustacy, tectonics and their controls on the depositional patterns of clinostratified shoreface carbonates (late Pliocene, Sicily). In: Colella A. (Ed) Strata and sequences on shelves and slopes, SEPM, Research Conference, Catania-Sicily, September 1998, Excursion Guidebook, 29-69.

Collins M.B., Rigler J.K., 1982. The use of settling velocity in defining the initiation of motion of heavy mineral grains, under unidirectional flow. Sedimentology 29, 419-426.

Critelli S., Le Pera E., Galluzzo F., Milli S., Moscatelli M., Perrotta S., Santantonio M., 2007. Interpreting siliciclasticcarbonate detrital modes in foreland basin systems: An example from Upper Miocene arenites of the central Apennines, Italy. In: Arribas J., Critelli S., Johnsson M.J. (Eds) Sedimentary Provenance and Petrogenesis: Perspectives from Petrography and Geochemistry. Geol. Soc. Am. Spec. Pap., 420, 107-133. doi:10.11 30/2006.2420(08). 
Dolan J.F., 1989. Eustatic and tectonic controls on deposition of hybrid siliciclastic/carbonate basinal cycles: Discussion with examples. Am. Ass. Petr. Geol. Bull., 73, 1233-1246.

Dorsey R.J., Kidwell S.M., 1999. Mixed carbonate-siliciclastic sedimentation on a tectonically active margin: Example from the Pliocene of Baja California Sur, Mexico. Geology, 27, 935-938.

Doyle L., Roberts H.H., 1988. AAPG/SEPM Carbonate to clastic facies change I. Am. Ass. Petr. Geol. Bull.

Dunham R.J., 1962. Classification of carbonate rocks according to depositional texture. In: Ham W.E. (Ed) Classification of carbonate rocks. Am. Ass. Petr. Geol. Mem., 1, 235-239.

Emery, D., Myers K.J., 1996. Sequence stratigraphy: Oxford, Blackwell Science, 304 p.

Feng J., Cao J., Hu K., Peng X., Chen Y., Wang Y., Wang M., 2013. Dissolution and its impacts on reservoir formation in moderately to deeply buried strata of mixed siliciclastic-carbonate sediments, northwestern Qaidam Basin, northwest China. Mar. Petrol. Geol., 39, 127-137.

Flemming B.W., 2016. Particle shape-controlled sorting and transport behavior of mixed siliciclastic/bioclastic sediments in a mesotidal lagoon, South Africa. Geo Mar. Lett., doi:10.1007/s00367-016-0457-3

Folk R.L., 1980. Petrology of Sedimentary Rocks. Hemphill Publishing, Austin.

Franco L.A., 1973. Deposition and diagenesis of the Yates Formation, Guadalupe Mountains and Central Basin Platform. Master Thesis, Texas Tech University.

Garcìa-Garcìa F., Soria J.M., Viseras C., Fernàndez J., 2009. High-frequency rhythmicity in a mixed siliciclasticcarbonate shelf (Late Miocene, Guadix basin, Spain): a model of interplay between climatic oscillations, subsidence, and sediment dispersal. J. Sediment. Res., 79, 302-315.

Gillespie J.L., Nelson C.S., 1997. Mixed siliciclastic-skeletal carbonate facies on Wanganui shelf, New Zealand: a contribution to the temperate carbonate. In: James N.P., Clarke J.A.D. (Eds) Cool water carbonates. Sediment. Geol. Spec. Publ., 56, 127-140

Gramigna P., Bassi D., Russo F., 2012 An Upper Miocene siliciclastic-carbonate ramp: depositional architecture, facies distribution, and diagenetic history (Capo Vaticano area, southern Italy). Facies, 58, 191-215.

Halfar J., Godinez-Orta L., Mutti M., Valdez-Holguín J.E., Borges J.M., 2004. Nutrient and temperature control on modern carbonate production: an example from the Gulf of California, Mexico. Geology, 32, 213-216.

Hartkamp-Bakker, C.A., 1991. Capillary oil entrapment in cross-bedded sedimentary structures of fluvial sandstone reservoirs. J. Petrol. Techn., 22, 959-970.

Hender K.L.B., Dix G.R., 2008. Facies development of a Late Ordovician mixed carbonate-siliciclastic ramp proximal to the developing Taconic orogen: Lourdes Formation, Newfoundland, Canada. Facies, 54, 121-149.

Komar P.D., Clemens K.E., 1986. The relationship between a grain's settling velocity and threshold of motion under unidirectional currents. J. Sediment. Petrol. 56, 258-266.

Kortekaas, Th.F.M., 1985. Water/oil displacement characteristics in cross-bedded reservoir zones. J. Petrol. Techn., 12, 917-926.

LaGesse J., Read J.F., 2006. Updip sequence development on a wave- and current-dominated, mixed carbonatesiliciclastic continental shelf: Paleogene, North Carolina, eastern U.S.A. Sediment. Geol., 184, 155-182.

Lee H.S., Chough S.K., 2011. Depositional processes of the Zhushadong and Mantou formations (Early to Middle Cambrian), Shandong Province, China: roles of archipelago and mixed carbonate-siliciclastic sedimentation on cycle genesis during initial flooding of the North China Platform. Sedimentology, 58, 1530-1572.

Lomando A.J., Harris P.M., 1991. Siliciclastic sequence, SEPM, Dallas. 
Longhitano S.G., 2011. The record of tidal cycles in mixed silici-bioclastic deposits: examples from small PlioPleistocene peripheral basins of the microtidal Central Mediterranean Sea. Sedimentology, 58, 691-719.

Longhitano, S.G., Chiarella, D., Muto, F., 2014. Three-dimensional to two-dimensional cross-strata transition in the lower Pleistocene Catanzaro tidal strait transgressive succession (southern Italy). Sedimentology, 61, 2136-2171.

Longhitano S.G., Sabato L., Tropeano M., Gallicchio S., 2010. A mixed bioclastic-siliciclastic flood-tidal delta in a microtidal setting: depositional architectures and hierarchical internal organization (Pliocene, southern apennine, Italy). J. Sediment. Res., 80, 36-53.

Longhitano, S.G., Chiarella, D., Di Stefano, A., Messina, C., Sabato, L., Tropeano, M., 2012. Tidal signatures in Neogene to Quaternary mixed deposits of southern Italy straits and bays. Sediment. Geol. 279, 74-96.

Maiklem W.R. 1968. Some hydraulic properties of bioclastic carbonate grains. Sedimentology, 10, 101-109.

Mansurbeg H., Caja M.A., Marfil R., Morad S., Remacha E., Garcia D., Martín-Crespo T., El-Ghali M.A.K., Nystuen J.P., 2009. Diagenetic Evolution and Porosity Destruction of Turbiditic Hybrid Arenites and Siliciclastic Sandstones of Foreland Basins: Evidence from the Eocene Hecho Group, Pyrenees, Spain. J. Sediment. Res. 79, 711-735.

Martinius A.W., 1995. Macrofauna associations and formation of shell concentrations in the Early Eocene Roda Formation (southern Pyrenees, Spain). Scripta Geologica, 108, 1-39.

Mantz P.A., 1977. Incipient transport of fine grains and flakes by fluids-extended shields diagram. J. Hydraul. Div. 103, 601-615.

Massari F., Chiocci F., 2006. Biocalcarenite and mixed cool-water prograding bodies of the Mediterranean Pliocene and Pleistocene: architecture, depositional setting and forcing factors. In: Pedley H.M., Carannante G. (Eds) CoolWater Carbonates: Depositional Systems and Palaeoenvironmental Controls. Spec. Publ. Geol. Soc., 255.

Massari F., D`Alessandro A., 2010. Icehouse, cool-water carbonate ramps: the case of the Upper Pliocene Capodarso Fm (Sicily): role of trace fossils in the reconstruction of growth stages of prograding wedges. Facies, 56, 47-58.

McIlreath I., Ginsburg R.N., 1982. Symposium 27: mixed deposition of carbonate and siliciclastic sediments. In: $11^{\text {th }}$ International Congress of Sedimentology, IAS 109-113.

McNeill D.F., Cunningham K.J., Guertin L.A., Anselmetti F.S., 2004. Depositional Themes of Mixed Carbonatesiliciclastics in the South Florida Neogene: Application to Ancient Deposits. In: Integration of outcrop and modern analogs in reservoir modeling. Am. Ass. Pet. Geol. Mem., 80, 23-43.

McNeill D.F., Klaus J.S., Budd A.F., Lutz B.P., Ishman S.E., 2012. Late Neogene chronology and sequence stratigraphy of mixed carbonate-siliciclastic deposits of the Cibao Basin, Dominican Republic. Geol. Soc. Am. Bull. 124, 35-58.

Mear C.E., Yarbrough D.V., 1961. Yates Formation in southern Permian basin of West Texas. Am. Ass. Petr. Geol. Bull. 45, 1545-1556.

Messina, C., Nemec, W., 2006. Sedimentological and statistical analysis of the Garn Formation in the Kristin field. Report to Statoil Research Centre, Trondheim, $82 \mathrm{pp}$.

Messina C., Rosso A., Sciuto F., Di Geronimo I., Nemec W., Di Dio T., Di Geronimo I., Maniscalco R., Sanfilippo R., 2007. Anatomy of a transgressive systems tract revealed by integrated sedimentological and palaeoecological study: the Barcellona P.G. Basin, northeastern Sicily, Italy. In: Nichols G., Paola C., Williams E.A. (Eds) Sedimentary Processes, Environments and Basins - A Tribute to Peter Friend, IAS Spec. Publ., 38, 367-399.

Messina, C., Nemec, W., Longhitano, S., 2009. Statistical properties of tidal dunes and their use in reservoir modelling. In: Abstracts IAS Annual Meeting, Alghero, 55 pp. 
Miller M.C., McCave I.N., Komar P.D., 1977. Threshold of sediment motion under unidirectional currents. Sedimentology, 24, 507-527.

Moissette P., Cornée J.J., Mannaï-Tayech B., Rabhi M., André J.P., Koskeridou E., Méon H., 2010. The western edge of the Mediterranean Pelagian Platform: A Messinian mixed siliciclastic-carbonate ramp in northern Tunisia. Palaeogeogr. Palaeoclimatol. Palaeoecol., 285, 85-103.

Molenaar N., Martinius A.W., 1995. Fossiliferous intervals and sequence boundaries in shallow marine, fan-deltaic deposits (Early Eocene, southern Pyrenees, Spain). Palaeogeogr. Palaeoclimatol. Palaeoecol., 121, 147-168.

Monstad S., 2000. Carbonate sedimentation on inactive fan-delta lobes: response to sea-level changes, Sant-Llorenc del Munt fan-delta complex, NE Spain. Sediment. Geol. 138, 99-124.

Moretti M., Tropeano M., van Loon A.J., Acquafredda P., Baldacconi R., Festa V., Lisco S., Mastronuzzi G., Moretti V., Scotti R., 2016. Texture and composition of the Rosa Marina beach sands (Adriatic coast, southern Italy): a sedimentological/ecological approach. Geologos, 22, 87-103.

Morsilli M., Bosellini F.R., Pomar L., Hallock P., Aurell M., Papazzoni C.A., 2012. Mesophotic coral buildups in a prodelta setting (Late Eocene, southern Pyrenees, Spain): a mixed carbonate-siliciclastic system. Sedimentology, 59, 766-794.

Mount J.F., 1984. Mixing of siliciclastic and carbonate sediments in shallow shelf environments. Geology, 12, $432-435$.

Mount J.F., 1985. Mixed siliciclastic and carbonate sediments: a proposed first-order textural and compositional classification. Sedimentology, 32, 435-442.

Mutti M., Simo J.A., 1993. Stratigraphic patterns and cycle-related diagenesis of upper Yates Formation, Permian, Guadalupe Mountains. In: Loucks R.G., Sarg J.F. (Eds) Carbonate sequence stratigraphy, recent developments and applications. Am. Ass. Petrol. Geol. Mem., 57, 515-534.

Nalin R., Ghinassi M., Basso D., 2010. Onset of temperate carbonate sedimentation during transgression in a lowenergy siliciclastic embayment (Pliocene of the Val d'Orcia Basin, Tuscany, Italy). Facies, 56, 353-368.

Nelson C.S., 1978. Temperate shelf carbonate sediments in the Cenozoic of New Zealand. Sedimentology, 25, 737-771.

Pettijohn J.F., 1954. Classification of sandstone. Journal of Geology, 62, 360-365.

Prager E.J., Southard J.B., Vivoni-Gallart E.R., 1996. Experiments on the entrainment threshold of well-sorted and poorly sorted carbonate sands. Sedimentology, 43, 33-40.

Puga-Bernabéu Á., Martín J.M., Braga J.C., Sànchez-Almazo I.M., 2010. Downslope-migrating sandwaves and platform-margin clinoforms in a current-dominated, distally steepened temperate-carbonate ramp (Guadix Basin, Southern Spain). Sedimentology, 57, 293-311.

Ringrose Ph., Nordahl K., Wen R., 2005. Vertical permeability estimation in heterolithic tidal deltaic sandstones. Petrol. Geosci., 11, 29-36.

Rossi V.M., Longhitano S.G., Mellere D., Dalrymple R.W., Steel R.J., Chiarella D., Olariu C., 2017. Interplay of tidal and fluvial processes in an early Pleistocene, deltafed, strait margin (Calabria, Southern Italy). Mar. Petrol. Geol., 87, 14-30.

Roveri M., Taviani M., 2003. Calcarenite and sapropel deposition in the Mediterranean Pliocene: shallow- and deepwater record of astronomically driven climatic events. Terra Nova, 15, 279-286.

Sanders D., Baron-Szabo R.C., 2005. Scleractinian assemblages under sediment input: their characteristics and relation to nutrient input concept. Palaeogeogr. Palaeoclimatol. Palaeoecol., 216, 139-181.

Slatt R.M., 2006. Stratigraphic reservoir characterization for petroleum geologists, geophysicists and engineers. Handbook of Petroleum Exploration and Production, 6, Elsevier. 
Slatt R.M., Galloway W.E., 1993. Geological heterogeneities. In: Morton Thompson D., Woods A.M. (Eds) Development geology reference manual. AAPG Methods in Exploration Series, 10, 278-281.

Smith D.G., 1994. Cyclicity or chaos? Orbital forcing versus non-linear dynamics. In: de Boer P.L., Smith D.G. (Eds) Orbital Forcing and Cyclic Sequences. IAS Spec. Publ., 19, 531-544.

Stemmerik L., Elvebakk G., Worsley D., 1999. Gipsdalen Group, Barents Sea, Norway. Petrol. Geosci., 5, $173-187$.

Tänavsuu-Milkeviciene K., Plink-Björklund P., Kirsimäe K., Ainsaar L., 2009. Coeval versus reciprocal mixed carbonate-siliciclastic deposition, Middle Devonian Baltic Basin, Eastern Europe: implications from the regional tectonic development. Sedimentology, 56, 1250-1274.

Thorkelson J.M., 1983. Depositional environments of select shelfal sands associated with the Permian Basin of West texas and southeastern New Messico. Master Thesis, University of Southwestern.

Thrana C., Talbot M.R., 2006. High-frequency carbonate-siliciclastic cycles in the Miocene of the Lorca Basin (Western Mediterranean, SE Spain). Geol. Acta, 3, 343-354.

Tirsgaard H., 1996. Cyclic sedimentation of carbonate and siliciclastic deposits on a late Precambrian ramp: the Elisabeth Bjerg Formations (Eleonore bay Supergroup), east Greenland. J. Sediment. Res., 66, 699-712.

Tropeano M., Sabato L. 2000. Response of Plio-Pleistocene mixed bioclastic-lithoclastic temperate-water carbonate systems to forced regressions: the Calcarenite di Gravina Formation, Puglia SE Italy. In: Hunt D., Gawthorpe R.L. (Eds.) Sedimentary Responses to Forced Regressions, Geological Society, London, Special Publication, 172 , $217-$ 243.

Tucker M.E., 2003. Sedimentary rocks in the field. Wiley.

van Buchem F.S.P., Allan T.L., Laursen G.V., Lotfpour M., Moallemi A., Monibi S., Motiei H., Pickard N.A.H., Tahmasbi A.R., Vedrenne V., Vincent B. (2010) Regional stratigraphic architecture and reservoir types of the Oligo-Miocene deposits in the Dezful Embayment (Asmari and Pabdeh Formations) SW Iran. Geological Society, London, Special Publication, 329, 219-263.

van Loon A.J., Moretti M., Tropeano M., Acquafredda P., Baldacconi R., Festa V., Lisco S., Mastronuzzi G., Moretti V., Scotti R., 2017. Tracing the Source of the Bio/Siliciclastic Beach Sands at Rosa Marina (Apulian Coast, SE Italy). In: Mazumder R. (Ed.) Sediment provenance influences on compositional change from source to sink. Elsevier, pp.25-47.

Vitale F.P., 1998. Stacking pattern and tectonics: Weld evidence from Pliocene growth folds of Sicily (central Mediterranean) Plio-Pleistocene record. In: De Graciansky P-C, Hardenbol J, Jacquin T, Vail PR (eds) MesozoicCenozoic sequence stratigraphy of European basins. SEPM Spec. Publ., 60, 181-199

Warzeski E.R., Cunningham K.J., Ginsburg R.N., Anderson J.B., Ding Z.D., 1996. A Neogene mixed siliciclastic and carbonate foundation for the Quaternary carbonate shelf, Florida Keys. J. Sediment. Res. 66, 788-800.

Wilson J.L., 1967. Cyclic and Reciprocal Sedimentation in Virgilian Strata of Southern New Mexico. GSA Amer. Bull., $78,805-818$.

Wilson J.B., 1988. A model for temporal changes in the faunal composition of shell gravels during a transgression on the continental shelf around the British Isles. Sediment. Geol., 60, 95-105.

Yose L.A., Heller P.L. (1989) Sea-level control of mixed-carbonate-siliciclastic, gravity-flow deposition: Lower part of Keeler Canyon Formation (Pennsylvanian), southern California. Geol. Soc. Am. Bull., 101, 427-439.

Zecchin M., Caffau M., 2011. Key features of mixed carbonate-siliciclastic shallow-marine systems: the case of the Capo Colonna terrace (southern Italy). Ital. J. Geosci. (Boll. Soc. Geol. It.), 130, 370-379 
Zecchin M., Caffau M., 2012. The vertical compartmentalization of reservoirs: An example from outcrop analog, Crotone Basin, southern Italy. Am. Ass. Petrol. Geol. Bull., 96, 155-175.

Zeller M., Verwer K., Eberli G., Massaferro J.L., Schwarz E., Spalletti L., 2015. Depositional controls on mixed carbonate-siliciclastic cycles and sequences on gently inclined shelf profiles. Sedimentology, 62, 2009-2037

Zinz L.Z., 1971. Environmental framework and diagenesis of the Yates formation, Apache Mountains, Culberson County, Texas. Master Thesis, Texas Tech University.

Zuffa G.G., 1980. Hybrid arenites: their composition and classification. J. Sediment. Res., 50, 21-29.

Zuffa G.G., 1985. Optical analyses of arenites: Influence of methodology on compositional results. In: Zuffa, G.G. (ed.) Provenance of Arenites: Dordrecht, Netherlands, NATO Advanced Study Institute Series, 165-189.

\section{FIGURE CAPTIONS}

Figure 1 - Scales of siliciclastic-carbonate mixing. (A) Compositional mixing observed at bed scale in the lower-middle Pliocene of the Acerenza Basin (Southern Italy). This type of mixing occurs when siliciclastic and carbonate fractions accumulate contemporaneously in space and time (after Chiarella and Longhitano, 2012). Strata mixing occurring at (B) lithofacies scale in the middle Devonian of the Baltic Basin (Eastern Europe) (modified from Tänavsuu-Milkeviciene et al., 2009) and at (C) stratigraphic scale in the Miocene of the Lorca Basin (SE Spain) (modified from Thrana and Talbot, 2006). Strata mixing occurs when the two heterolithic fractions are organized into different bed (lithofacies scale) or bed-set packages (stratigraphic scale).

Figure 2 - Coexistence of compositional and strata mixing in A) the lower Pleistocene of the Catanzaro Basin (southern Italy), B) the upper Pliocene of the Capodarso Formation (Enna-Caltanissetta Basin, Italy), and (C)the upper Miocene of the Guadix Basin (SE Spain) (modified from Puga-Bernabéu et al., 2010). Small scale (bed scale) compositional mixing as part of a large scale (stratigraphic scale) strata mixing.

Figure 3 - Conceptual models showing different types of mixing processes (after Mount, 1984). Punctuated mixing results into a lithofacies-scale mixing (strata mixing). Facies mixing can result both in a bed scale compositional mixing and/or a stratigraphic-scale strata mixing. In situ mixing results into a bed-scale mixing (compositional mixing).

Figure 4 - Compartmentalization in mixed deposits characterized by compositional mixing. (A) Mixed siliciclasticcarbonate ripples in the lower-middle Pliocene of the Acerenza Basin (Southern Italy). (B) Close-up view from the previous photograph showing the siliciclastic-carbonate segregation among lamina-sets. (C) Siliciclastic (s) - bioclastic (b) segregation in foreset-lamina bundles observable in Tortonian tidal cross-strata of the Amantea Basin (Southern Italy) showing the lamina-scale variations in permeability. (D) Photomicrograph showing segregation at the lamina scale (Acerenza Basin). Coin are $2.3 \mathrm{~cm}$ in diameter

Figure 5 - Pictures highlighting reservoir features (compartmentalization) for the strata mixing. (A) Alternation between siliciclastic and carbonate beds in the middle Devonian of the Baltic Basin (Eastern Europe). (B) Large scale (stratigraphic scale) alternation between reservoir-prone and non-reservoir units in the upper Pliocene Capodarso Formation (Enna-Caltanissetta Basin, Italy). (C) Stratigraphic scale mixing in the upper Eocene of the Aínsa-Jaca Basin (Southern Pyrenees, Spain) showing the occurrence of carbonate units (reservoir-prone) embedded within siliciclastic units (dotted=siliciclastic units; bricks=carbonate units) (redrawn after Morsilli et al., 2012). 


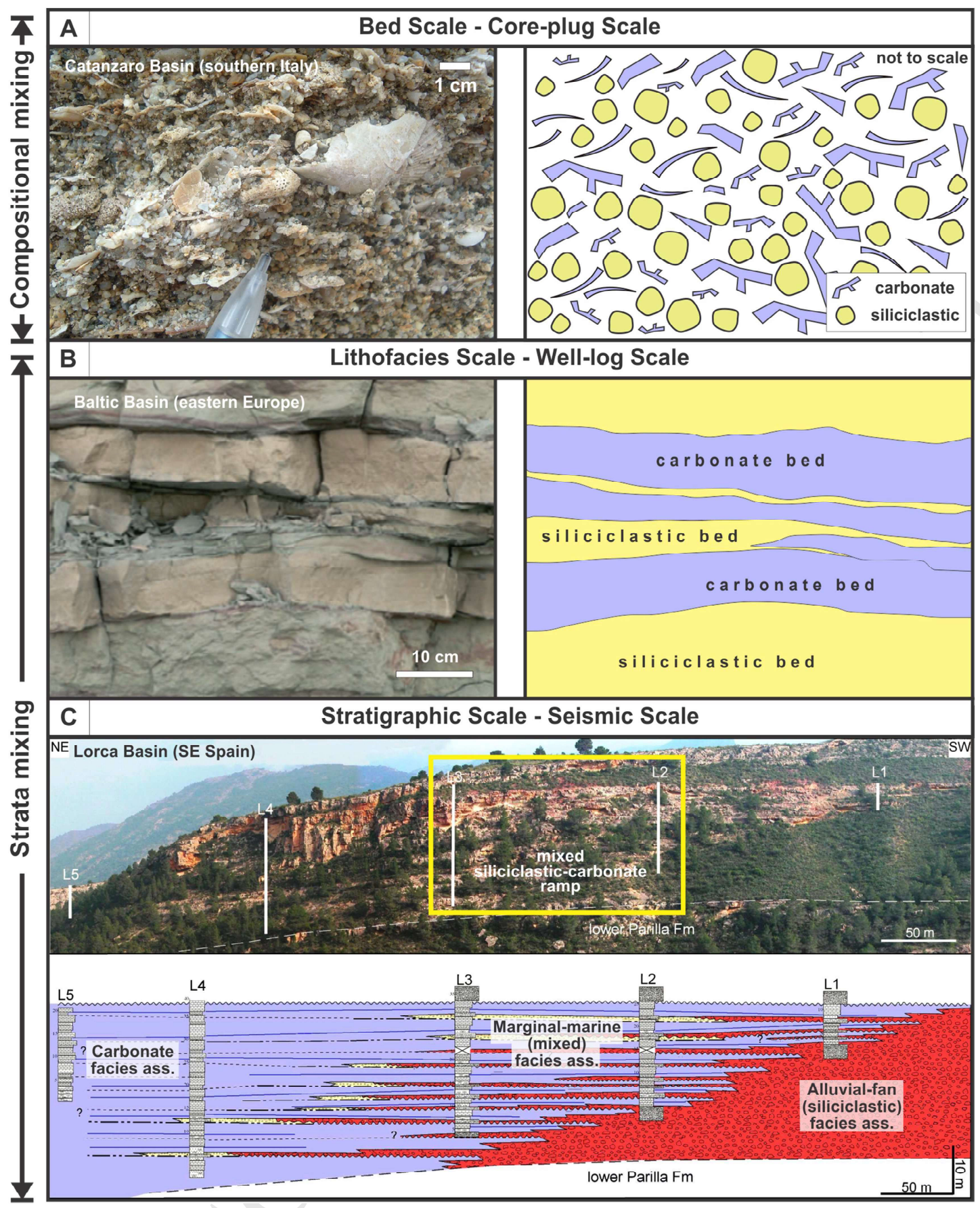




\section{ACCEPTED MANUSCRIPT}
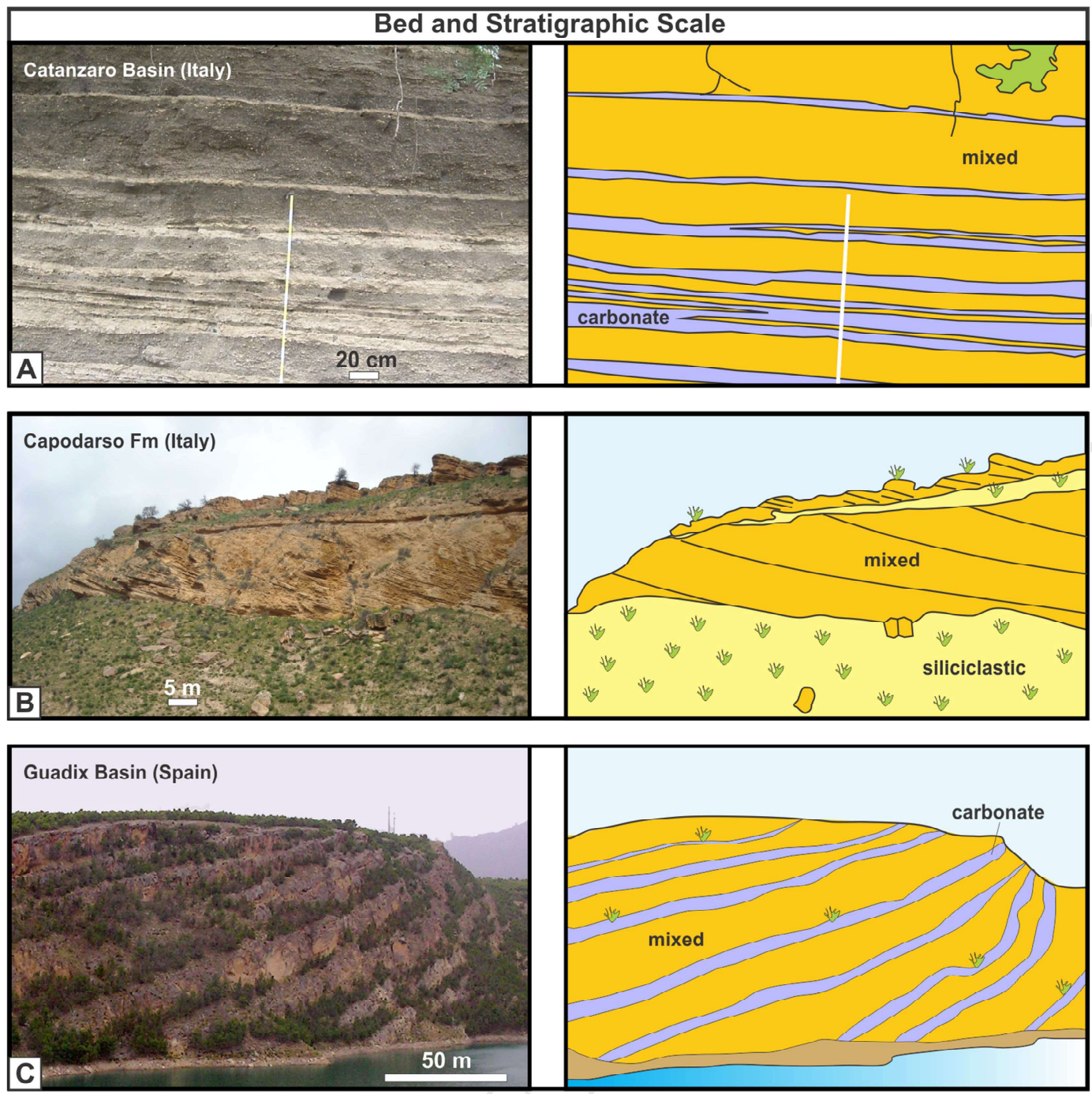


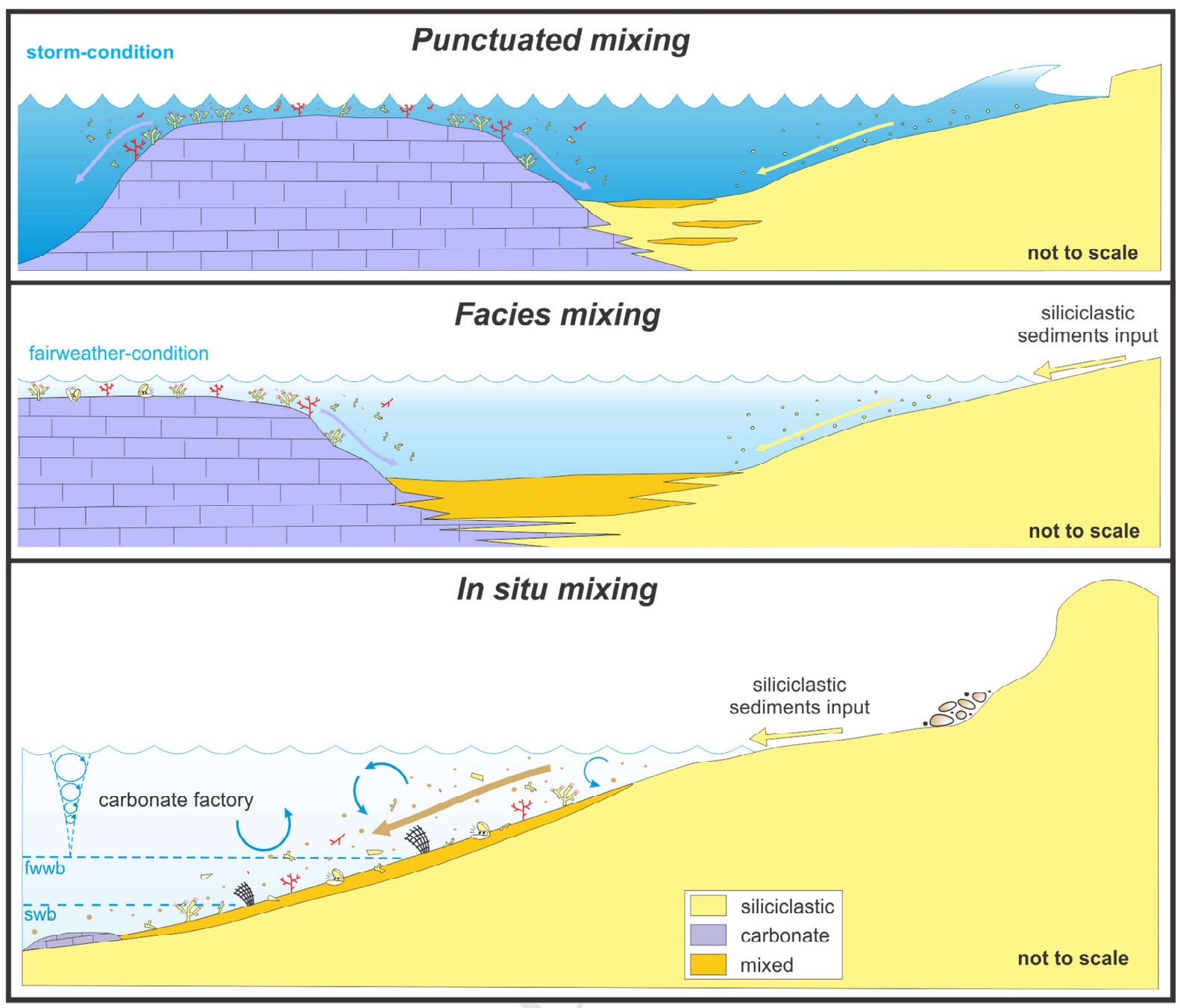



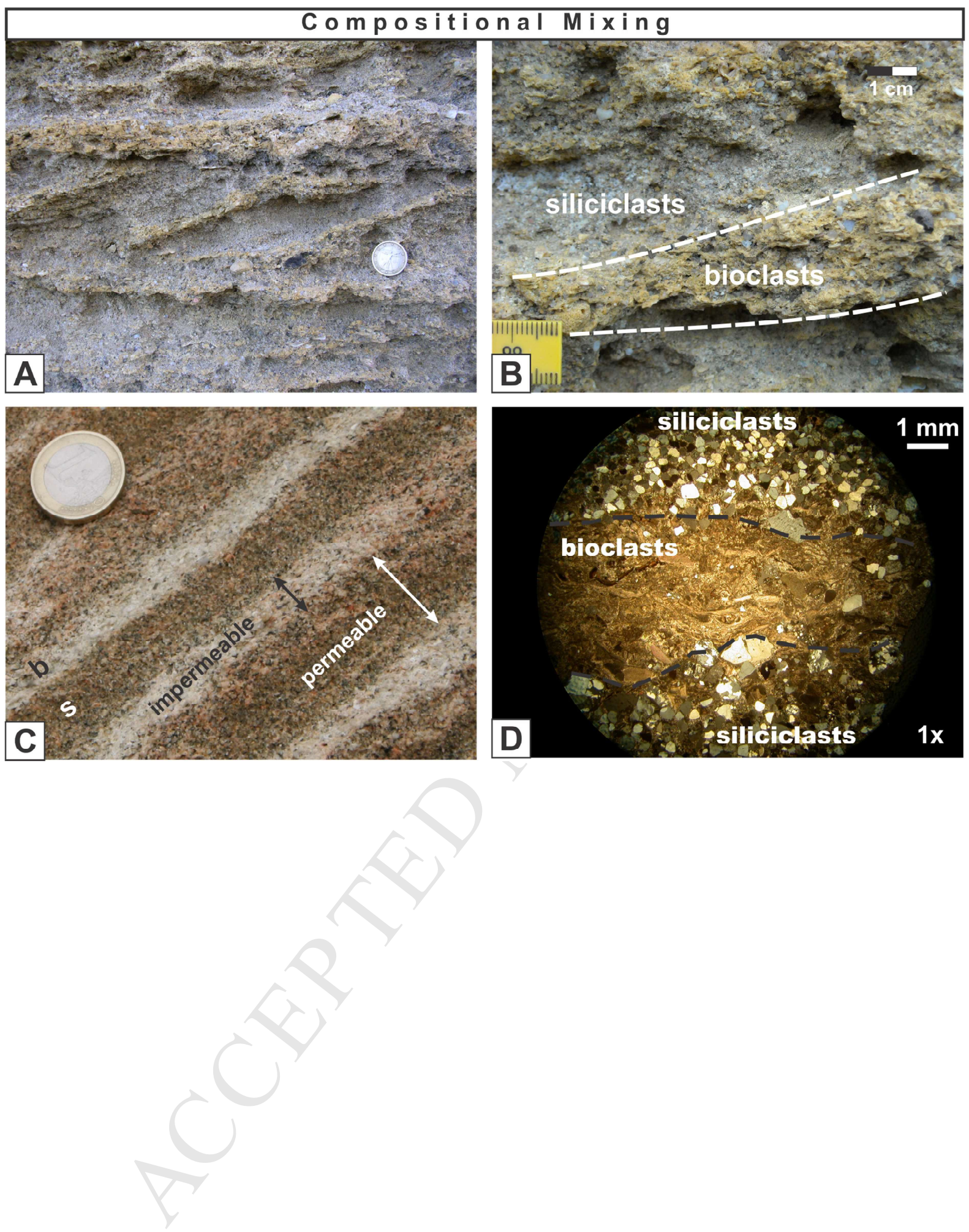


\section{ACCEPTED MANUSCRIPT}
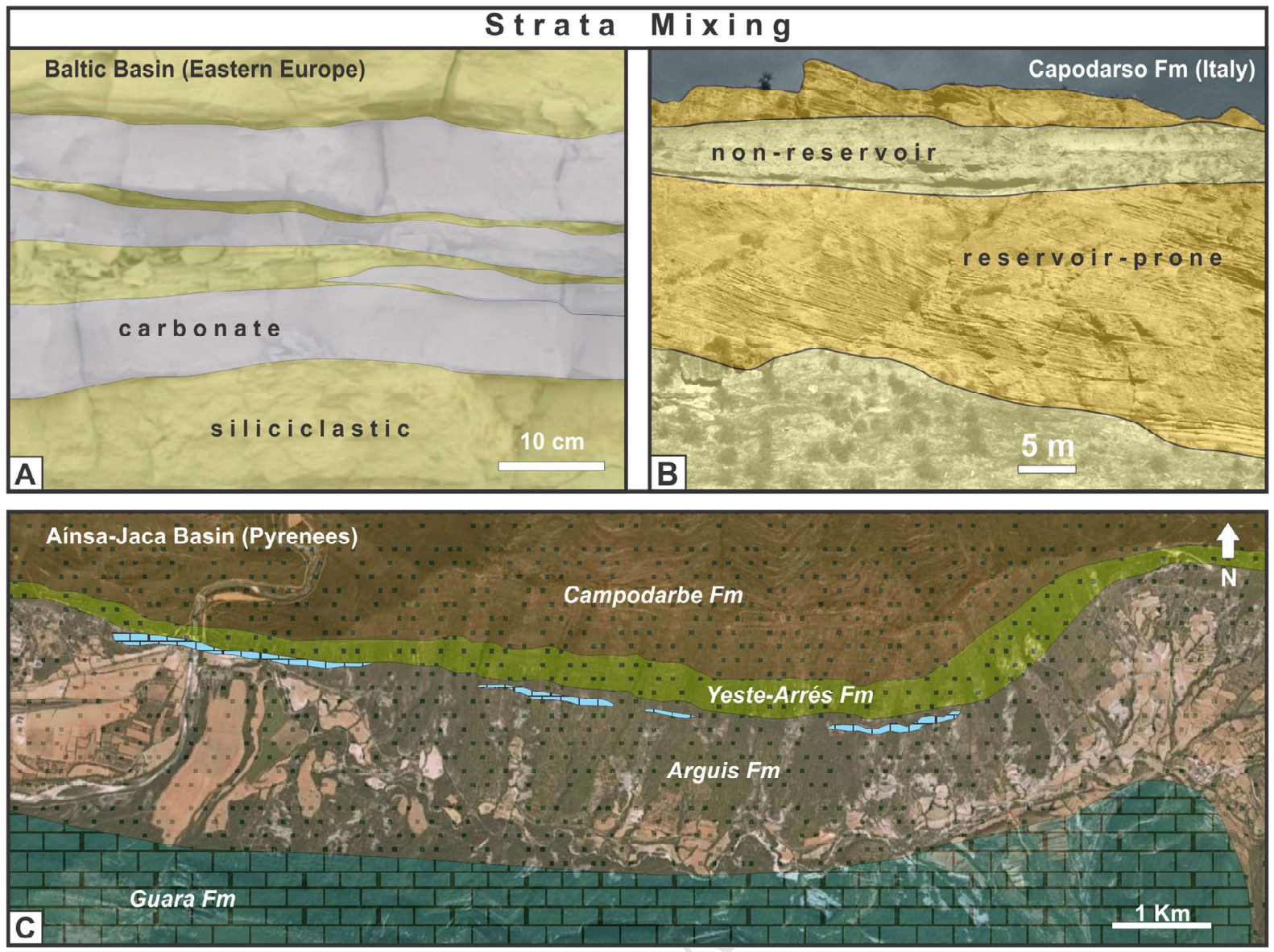
- Mixed siliciclastic-carbonate deposits organization

- Different types of mixing operating at different scales: bed/core-plug scale; lithofacies/welllog scale; and stratigraphic/seismic scale;

- Compositional mixing reflecting the contemporaneous accumulation of the two heterolithic fractions

- Strata mixing results from the alternation of the two heterolithic fraction in time

- Internal heterogeneity and the lateral and vertical reservoir compartmentalization 